\title{
Undergraduates' Awareness of English Irregular Verbs
}

\author{
Harits Setyawan \\ harits.setyawan@staff.itera.ac.id \\ Institut Teknologi Sumatera
}

\begin{abstract}
The objectives of this research were to find out undergraduates' awareness of English irregular verbs and to find out what errors that the students made in using the irregular verbs. This research was conducted at University of Teknokrat Indonesia. The population of this research was the first semester students. There were 30 university students who were chosen as the samples. They were all S1 English Literature students. The data of this research were collected through a written task. The task was designed to measure the students' ability in using irregular verbs in sentences telling about past events. There were 140 irregular verbs tested to the students. The result of the research showed that the undergraduates' awareness of English irregular verbs is low; 22 (73.3\%) out 30 students made errors in using English irregular verbs. The errors varied into three types; using the rule of regular verbs for irregular verbs, using simple form verbs for past events, and creating new words which did not exist in English vocabulary. The highest number of error was placed by applying the rule of regular verbs for irregular verbs with 14 incorrect verbs (53.8\%), the second position was placed by using simple form verbs for past events with 9 incorrect verbs (34.6\%), and the third position was placed by creating new words which did not exist in English vocabulary with 3 incorrect verbs (11.5\%). The results of this study indicate that students in which English is a foreign language might still have insufficient English vocabulary when they come to higher schools.
\end{abstract}

Keywords: Foreign language, error, irregular verb

\section{Introduction}

Students who learn English as a second and a foreign language face many obstacles that make them difficult to achieve native-speaker-like proficiency. Richards, Jack (1971) explains that people who speak second languages may not speak or write them with native-speaker-like fluency. These second-language deficiencies maybe the results of (1) interference, the use of aspects of another language at a variety of levels; (2) strategies of learning such as over overgeneralization and analogy by means of which the learner tests out his hypotheses about the structure of the language; (3) strategies of assimilation, in which the learner makes his learning task easier; and (4) strategies of communication, whereby the learner adapts what he knows into an efficient communication model, producing an optimal utility grammar from what he knows of the language. It implies that making errors when learning a language commonly happens. Investigating students' errors in learning a language, such as English, has been done by many researchers. Jayasusundara \& Premarathna (2011: 2) found that the highest number of errors reported was under Grammar. Similarly, Ciesielkiewicz (2015: 135) found that the grammar-syntax and spelling mistakes were most common, whereas the punctuation and lexical categories present a lower frequency of errors. More specifically Rini (2014: 242) describrs that the dominant errors students made are error of using preposition, using noun, simple present tense, simple past tense, word choices, and degrees of comparison. Furthermore, studies about theories in errors have also been conducted by researchers. Khansir (2012: 1027) examines in detail the three most influential error theories: Contrastive analysis, Error analysis and Interlanguage theory. Even in a conclusion, Gurtubay (2009: 140) adds that learners' errors in L2 are indicators of learning problems in a foreign language, in our case, learning of English language.

Similar like what other researchers have found, errors in English grammar in case of irregular verbs are also found. English has two types of verb; regular and irregular verbs. Regular verbs are the type of verb which are modified by adding ending -ed for past forms. In contrast to regular verbs, irregular verbs are not modified by adding ending -ed for past events. They do not have a regular pattern that can be easily remembered. This characteristic makes irregular verbs often cause problems for students. In one occasion of teaching and learning process, the researcher found that some of students who were taught by the researcher in class Structure 1 made inappropriate use of irregular verbs when they were asked to write some sentences about what they did in the past on the whiteboard. What they wrote were among them: a) The lecturer teached us yesterday, b) We go to beach last week, and c) He bougt a pen two days ago. The inappropriate uses of irregular verbs made the researcher interested in investigating further to find out how the students' awareness of English irregular verbs was and if the 
students made errors in using irregular verbs, what kinds of errors that they made. Furthermore, if the students truly had problems in using irregular verbs, it would be necessary to investigate which parts they were weak in. With the existing data that the researcher got, the researcher had not been able to discover it. The researcher was interested to investigate further through a research to find out the answers. Besides, investigating it can find out which parts of learning materials the students are weak in. It also enables lecturers, teachers, and prospective teachers to evaluate the way they teach and determine which way that is the best for their students. Hence, the finding of this research can theoretically confirm the previous theory relating to errors in using English irregular verbs and practically be the source of information about students' errors in using English irregular verbs.

Analyzing students' errors is beneficial for both teachers and students. According to Kotsyuk (2015: 389), teachers can be made aware of the difficult areas to be encountered by the students and pay special attention and devote emphasis to them. It means that by analyzing errors and knowing difficult areas, what teachers do during teaching and learning process can more precisely answer the students' problems and thus problems in English language learning faced by students are solved in the classroom. Similarly, Hasyim (2002: 42) explains that although errors are bad things in learning English as a foreign language, error analysis is advantageous for both learners and teachers. For learners, error analysis is needed to show them in what aspect in grammar which is difficult for them, whereas for teachers, it is required to evaluate themselves whether they are successful or not in teaching English. Furthermore, Fang \& Xue-mei (2007: 10) state that teachers should employ different and flexible error treatment strategies in accordance with the teaching objectives, students' linguistic competence, their affective factors and the effectiveness of the error correction. It implies that to give the right error treatment strategies, teachers need to find out what errors that students commit. In agreement, Al-Khresheh (2016: 49) explains error analysis can enable second language teachers to find out different sources of second language errors and take some pedagogical precautions towards them. Moreover, Error Analysis can provide a good methodology for investigating second language learners' errors. Once the causes or sources of errors are discovered, it is probable to conclude and decide on the remedy. Considering the benefits of analyzing students' errors in learning, this study which aims to investigates undergraduates' awareness of English irregular verbs and what errors that they make in using the irregular verbs is accordingly conducted.

\section{Method}

This research was conducted qualitatively. It focused on the students' errors in using irregular verbs in their sentences to find out their awareness of English irregular verbs and what errors that they made in using English irregular verbs. The samples were chosen purposefully with criteria; they were first semester students and they came from the same study program in this case S1 English literature of University Teknokrat Indonesia. There was no differentiation in age and gender. Thus, as long as the students were in the first semester and came from the same study program, they were eligible to become the samples. In data collecting method, the researcher used a written task which required the students to write sentences telling about past events by using the provided English irregular verbs. The students were not informed that English verbs given to them were all irregular. There were 140 English irregular verbs that the students had to make into sentences. However, it was not a must for them to finish all. They had 60 minutes to write as many sentences as possible. The researcher came directly to the location of the research and collected the data. In analyzing the data, the researcher analyzed errors in irregular verbs only. Therefore, other errors that the students made in their sentences were not analyzed.

\subsection{Identify Subsections}

The participants had been experienced in English. English had been taught to the students since they were at Junior High School and English irregular verb was one of topics taught to them during the time. In conducting this research, the researcher followed some procedures: (a) constructing the task, (b) determining the samples, (c) collecting the data, (d) selecting the data, and (e) analyzing the data. Since the research was focused on students' errors in using irregular verbs, the data collecting instrument was constructed to measure students' ability in using irregular verbs. After the data collecting instruments had been constructed, the researcher came to the location of the research to collect the data. When the data had been collected, the data were selected and only errors in using irregular verbs were taken. Finally, errors in using irregular verbs were analyzed to find out how undergraduates' awareness of English irregular verbs was and what errors that they made in using English irregular verbs in sentences which told about past events. 


\subsection{Participant Characteristics}

The participants were S1 English literature students. They had studied English when they were at Junior High Schools and Senior High Schools, so they had had basics in English. They continued to higher school and took S1 English Literature at University Teknokrat Indonesia. They were all in the first semester when this research was being conducted. The eligible participants were the first semester students of S1 English Literature. Students with higher semesters were exclusion criteria. There were no restrictions on demographic characteristics. Therefore, the participants varied in age, marital status, or the number of birth.

\subsection{Sampling Procedures}

The sampling method which was used in this research was purposive sampling. A systematic plan was used. The samples were chosen purposefully with criteria; they were first semester students and they came from the same study program. From the population, 30 students were chosen as the samples with further consideration, such as they were willing to cooperate and the data collection schedule did not conflict with their schedules at campus. The location where the data were collected was University Teknokrat Indonesia. There were no payments made to the participants and it was monitored directly by the researcher.

\subsubsection{Sample Size, Power, and Precision}

The intended size of the sample was 30 students and there were no separate conditions used in this research. The target population of the sample was completely achieved.

\subsubsection{Measures and Covariates}

The method used to collect data was documentation in form of a written task measuring the students' ability in using English irregular verbs to tell about past events through sentences. There were 140 irregular verbs tested to the students. Before doing the task, the students were given a direction and asked to make sentences about past events by using the provided verbs. In doing the task, they were not allowed to open any dictionary and had one hour to finish the task. Furthermore, in analyzing undergraduates' awareness of English irregular verbs, the researcher used the following formula;

$$
\begin{array}{lll}
0-35 & \% & \text { of the samples made errors: Good, } \\
36-70 & \% & \text { of the samples made errors: Fair, } \\
71-100 & \text { of the samples made errors: Low. }
\end{array}
$$

If the number of students who made errors in using English irregular verbs achieved 71 to $100 \%$, it meant undergraduates' awareness of English irregular verbs was low. If the number of students who made errors in using English irregular verbs achieved 36 to 70\%, it meant undergraduates' awareness of English irregular verbs was fair. If the number of students who made errors in using English irregular verbs achieved 0 to $35 \%$, it meant undergraduates' awareness of English irregular verbs was good. Hence, in relation with what errors that undergraduates made when they used English irregular verbs, it would be determined after the data had already been analyzed.

\subsubsection{Research Design}

The samples were not put into conditions that were manipulated. They fully realized that they were being observed. The researcher met the students directly. They were gathered in a class and told what the researcher was going to do. The task was also given directly by the researcher to the students. The researcher gave the students directions and then asked them to do the task. There were no multiple conditions. The students were assigned to do the same task and had the same time limit to finish it.

\subsubsection{Experimental Manipulations or Interventions}

This research was intended to find out undergraduates' awareness of English irregular verbs and what errors that they made in using English irregular verbs in their sentences. Therefore, there were no interventions or manipulations used in this research. There were also no control groups and experimental groups. 


\section{Discussion}

Having analyzed the data, the researcher found that 22 out of 30 samples involved in this research made errors in using English irregular verbs. The following table shows the overall errors that the students made in using irregular verbs in their sentences.

Table 1. Errors that the students made when they used English irregular verbs

\begin{tabular}{|c|l|l|l|l|}
\hline No & \multicolumn{1}{|c|}{ Students' Sentences } & \multicolumn{1}{c|}{$\begin{array}{c}\text { Simple } \\
\text { Form }\end{array}$} & Simple Past & \multicolumn{1}{|c|}{$\begin{array}{c}\text { Past } \\
\text { Participle }\end{array}$} \\
\hline 1 & The dog catch the ball on the air. & catch & Caught & caught \\
2 & I clinged with my comimend yesterday. & cling & clung & clung \\
came & come \\
3 & I come to school in the last morning. & cost & cost & cost \\
4 & I buy a apple with costed is Rp. 5000 yesterday. & creep & crept & deapt \\
5 & Rida creeped on the floor in the morning. & deal & dealt & dealt \\
6 & I dealed a money with you yesterday. & draw & drew & dug \\
7 & I diged Rina as my teacher yesterday. & eat & ate & drawn \\
8 & I drawed a doll in the last morning. & fall & fell & fallen \\
9 & I aet a meatball in the last night. & feed & fed & fed \\
10 & He falled from the car yesterday. & fight & fought & fought \\
11 & Fridechicken feed the famous in the world last years. & flee & fled & fled \\
12 & Some people fighted with the students last mounth. & fling & flung & flung \\
13 & She flee from the prison. & forbid & forbade & forbidden \\
14 & Retno fling stone in my house a minutes ago. & forsook & forsaken \\
15 & My father forbident me go to watch movie. & froeze & frozen \\
16 & My mother fosaked the cake yesterday morning. & give & gave & given \\
17 & My ice cream is freezed in refrigerator. & grind & ground & ground \\
18 & She gaves money to her friend one minutes ago. & lead & led & led \\
19 & I grinded clothes yesterday. & let & let \\
20 & My father lead this project. & lose & lost & lost \\
21 & She lets me me go from her house yesterday. & taught & taught \\
22 & They loses their key last day. & thrust & thrust \\
23 & Mr Harist was teached structure class 1 this morning. & teach & thrust & woke \\
24 & You should thrusted my promise. & wake & woke & woken \\
25 & I wake up at 5 o'clock yesterday. & wound & wound \\
26 & My brother winded his clothes cause the rain two day ago. & wind & wound \\
\hline
\end{tabular}

The number of students who made errors in using English irregular verbs achieves 22 students or $73.3 \%$ of the overall students involved in this research. Based on the formulation that the researcher had previously described, it can be concluded that undergraduates' awareness of English irregular verbs is low. This finding indicates that students who have graduated from Senior High Schools do not have sufficient English vocabulary when they enter higher schools. Furthermore, all samples involved in this research came from English Literature study program. It means that a worse condition might happen to students whose study programs are not specified to English. However, further research to reveal that condition needs to be conducted as what other researchers have conducted, such as: Gunjal (2012: 23) who finds that the students of 9th Std. of Ahwa Taluka has Moderate English Vocabulary Achievement.

Undergraduates' low awareness of English irregular verbs can be caused by many factors; both internal factors which come from the students themselves and external factors which come from teachers, curriculums, tests, etc. Being seen from the internal factors, it might happen because the students are not interested in learning English. They choose English study program because of other factors, not because of their genuine interest. As Yufrizal (2008: 113) explains, another major dispute about motivations and second language learning is whether it is better to say that motivation predict success (Gardner's position) or that success predicts motivation (a contrary position more popular in psychology), in that the more successful one has been in language learning, the more motivated one will be to learn more. Furthermore, external factors might come from teaching strategies which do not drive the students to learn better, tests that do not measure what should be measured, curriculum that does not answer the students' needs, etc. As Alqahtani (2015: 31) suggests that before presenting the meaning or form of vocabulary 
items, teachers need to notice the type of the vocabulary, the students' level and characteristics, and also the value of the techniques for the learners. In other words, students' age, level of education as well as English proficiency ...etc may affect their learning, so teachers need to be aware of these differences when applying their teaching techniques. They can further provide their students with vocabulary learning strategies with opportunities to encounter words repeatedly and in more than one context.

Having differentiated the students' errors in using English irregular verbs, the researcher found that there were three types of errors in using English irregular verbs. The highest proportion of errors was occupied by using the rule of regular verbs for irregular verbs. The following table shows errors that the students made by applying English regular verb rule for English irregular verb. As known, to change English regular verbs to their simple past form, it is done only by giving ending -ed.

\section{Table 2. Errors of applying English regular verb rule to English irregular verb}

\begin{tabular}{|c|l|}
\hline No & Students' Sentences \\
\hline 1 & I clinged with my comimend yesterday. \\
2 & I buy a apple with costed is Rp. 5000 yesterday. \\
3 & Rida creeped on the floor in the morning. \\
4 & I dealed a money with you yesterday. \\
5 & I diged Rina as my teacher yesterday. \\
6 & I drawed a doll in the last morning. \\
7 & He falled from the car yesterday. \\
8 & Some people fighted with the students last mounth. \\
9 & My mother fosaked the cake yesterday morning. \\
10 & My ice cream is freezed in refrigerator. \\
11 & I grinded clothes yesterday. \\
12 & Mr Harist was teached structure class 1 this morning. \\
13 & You should thrusted my promise. \\
14 & My brother $\underline{\text { winded }}$ his clothes cause the rain two days ago. \\
\hline
\end{tabular}

Students who applied English regular verb rule to English irregular verb might have realized that they had to use verbs in simple past forms to tell about past events. However, the students didn't know the simple past forms of verbs that they used. As time was limited to finish the task, they took the risk by adding ending -ed to verbs that they used to make the verbs in their simple past forms. In fact, all verbs that they used were English irregular verbs. Furthermore, the researcher found that the second highest proportion of errors that the students made when they used English irregular verbs was using simple form verbs to tell about past events. As known, English simple form verbs are used to express about present time, habitual actions, or facts. Thus, using English simple form verbs in sentences telling about past events is not appropriate. The following table shows the sentences that used English simple form verbs though the students had previously been instructed to write sentences telling about past events.

\section{Table 3. Errors of using English simple form verbs to tell about past events}

\begin{tabular}{|c|l|}
\hline No & Students' Sentences \\
\hline 1 & The dog catch the ball on the air. \\
2 & I come to school in the last morning. \\
3 & Fridechicken feed the famous in the world last years. \\
4 & She flee from the prison. \\
5 & Retno fling stone in my house a minutes ago. \\
6 & My father lead this project. \\
7 & She lets me me go from her house. \\
8 & They loses their key last day. \\
9 & I wake up at 5 o'clock yesterday. \\
\hline
\end{tabular}

This kind of errors might have happened because the students did not know that they had to modify English simple form verbs into English simple past form verbs when they told about past events. As the result, they kept using English simple form verbs though having been previously instructed to write sentences telling about past events. This finding also implied that students who came to higher schools and chose English study program had not certainly had a good mastery of simple present tense and simple past tense. The last type of errors that the 
researcher found, and also the smallest proportion among the other errors, was creating new forms of verbs which did not exist in English vocabulary. The following table shows errors that that the students made when they modified English irregular verbs into new forms of verbs that did not exist in English vocabulary.

Table 4. Errors of modifying English irregular verbs into new forms of verbs which do not exist

\begin{tabular}{|c|l|}
\hline No & Students' Sentences \\
\hline 1 & I aet a meatball in the last night. \\
2 & My father forbident me go to watch movie. \\
3 & She gaves money to her friend one minutes ago. \\
\hline
\end{tabular}

Similar with the first type of errors that the researcher found, the third type of errors might have happened because the students realized that the verbs given to them must have been modified into simple past forms in sentences telling about past events. However, the student did not know the simple past forms of verbs that they used. Since they knew that the verbs were not English irregular verbs, they decided not to give ending $-e d$. They then constructed new forms of verbs that actually did not exist in English vocabulary. In relation with error analysis, Dulay (1982:146) classifies errors based on Surface Strategy Taxonomy into four types; Omission, Addition, Misformation, and Misordering. Omission errors are characterized by the absence of an item that must appear in a well-formed utterance. Addition errors are the opposite of omissions. They are characterized by the presence of an item which must not appear in a well-formed utterance. Misformation errors are characterized by the use of the wrong form of the morpheme or structure. Misordering errors are characterized by the incorrect placement of a morpheme or a group of morphemes in an utterance. However, the researcher found a new type of errors which cannot be categorized into errors based on Surface Strategy Taxonomy. The researcher calls the error creating new words which do not exist. It can be seen from the third type of errors where the students wrote aet, forbident, and gaves. The words do not exist in English vocabulary.

\section{Conclusion}

The result of this research shows that undergraduates' awareness of English irregular verbs is low. It can be seen from the total number of students who made errors in using English irregular verbs which achieves $73.3 \%$. It implies that students who have graduated from Senior High Schools do not have sufficient English vocabulary when they come to higher schools and future research about students' English vocabulary achievement when they enter higher schools should be conducted to discover more facts. Furthermore, errors that the students made when they used English irregular verbs can be classified into three types: (a) the use of regular verb rule for irregular verb, (b) the use of simple form verb for past event, and (c) creating new words which do not exist. The third type of errors, creating new words which do not exist, cannot be categorized into any of error categorizations based on Surface Strategy Taxonomy by Dulay. It implies that research on error analysis should be done further to discover things that have not been discovered in the past.

Here, some suggestions given by the researcher in relation with the result of the research are: (a) different from regular verbs, irregular verbs do not have any pattern that can easily be learnt. Therefore, the students have to memorize them, (b) when making sentences about past events, the verbs in the sentences must be in the past form. Therefore, the students also need to learn about the use of simple form, simple past, and past participle, (c) learning vocabulary needs time. The students cannot acquire thousand words in a day. Therefore, they should learn it gradually by memorizing a number of word every day.

\section{References}

Al-Khresheh. 2016. A Review Study of Error Analysis Theory. International Journal of Humanities and Social Science Research. Volume 2, Page 49-59.

Alqahtani. 2015. The Importance of Vocabulary in Language Learning and How to Be Taught. International Journal of Teaching and Education. Volume 3, No. 3.

Ciesielkiewicz \& Márquez. 2015. Error Analysis and Its Relevance to Teaching ESL Composition. International Journal of Linguistics. Volume 7, No. 5.

Dulay, et al. 1982. Language Two. New York: Oxford University Press. 
Fang \& Xue-mei. 2007. Error Analysis and the EFL Classroom Teaching. US-China Education Review. Volume 4, No. 9.

Gunjal. 2012. A Study of English Vocabulary Achievement of 9th Std. students of Ahwa Taluka. International Multidisciplinary e-Journal. Volume 1, Issue 5.

Gurtubay. 2009. Lexical Error Analysis in the Written Production of Students of English as a Second Language: A Plot Study. ES. Volume 30, Page 129-141.

Hasyim. 2002. Error Analysis in the Teaching of English. Puslit Petra Journal. Volume 4, No. 1.

Jayasundara \& Premarathna. 2011. A Linguistics Analysis on Errors Committed in English by Undergraduates. International Journal of Scientific and Research Publications. Volume 1. Issue 1.

Khansir. 2012. Error Analysis and Second Language Acquisition. Theory and Practice in Language Studies. Volume 2, No. 5.

Kotsyuk. 2015. English Language Error Analysis of the Written Texts Produced by Ukrainian Learners: Data Collection. Cognitive Studies. Volume 15, Page 389-395.

Richards, Jack. 1971. Error Analysis and Second Language Strategies. Department of Linguistics, University Laval: Quebec, Canada.

Rini. 2014. The Error Analysis on the Students of English Department Speaking Scripts. Register. Volume 7, No. 2.

Yufrizal. 2008. An Introduction to Second Language Acquisition. Bandung. Pustaka Reka Cipta. 